\title{
Blood-aqueous barrier deterioration following retained metallic corneal foreign body: A laser flare photometric study
}

\author{
디 İsmail Umut Onur, M.D., ㄴ) Sibel Zırtıloğlu, M.D., @ Ozan Sonbahar, M.D., \\ (1) Ercan Çavuşoğlu, M.D., ㄴ) Ulviye Yiğit, M.D.
}

Department of Ophthalmology, University of Health Sciences, İstanbul Bakirköy Dr. Sadi Konuk Training and Research Hospital, İstanbul-Turkey

\begin{abstract}
BACKGROUND: This study aims to use laser flare photometry to evaluate flare changes in patients following corneal damage from a metallic foreign body (FB).

METHODS: Foreign body injured eyes and the healthy fellow eyes of 54 consecutive patients were studied in this comparative, observational, cross-sectional study. Flare levels were analyzed according to demographics, history of previous exposures, foreign body location, and foreign body penetration into the injured cornea.
\end{abstract}

RESULTS: The mean flare value was significantly higher for the eyes with corneal foreign body injury compared to the fellow-control eyes $(11.35 \pm 14.17 \mathrm{ph} / \mathrm{ms}$ and $6.30 \pm 3.8 \mathrm{I} \mathrm{ph} / \mathrm{ms}$, respectively) $(\mathrm{p}=0.014)$. The mean flare values were significantly lower in eyes with a history of more than one previous corneal foreign body removal flare values than in other eyes $(p=0.029)$.

CONCLUSION: Flare is increased by corneal foreign body exposure. However, eyes that experience multiple previous corneal foreign body exposures may show relatively low flare, probably due to corneal desensitization.

Keywords: Anterior chamber reaction; corneal foreign body; laser flare photometry.

\section{INTRODUCTION}

A non-penetrating but retained corneal foreign body $(\mathrm{FB})$ is the most common, although inherently preventable, type of eye injury. ${ }^{[1]} \mathrm{FB}$ is a frequently occurring injury in construction and metal industry workers due to occupational accidents involving metallic FBs. ${ }^{[I]}$ Corneal FBs may decrease the quality of vision by causing scars on the visual axis and by triggering secondary infections ranging from keratitis to endophthalmitis. ${ }^{[2]}$

Under normal conditions, the anterior chamber of the eye is an optically empty space. ${ }^{[3]}$ However, disruption of the bloodocular barriers leads to the leakage of serum proteins into the anterior chamber. ${ }^{[3]}$ Inflammation increases the amount of protein in the aqueous humor by promoting the deterioration of the blood-aqueous barrier (BAB), ${ }^{[4]}$ and the amount of protein can be subjectively evaluated using slit-lamp biomicroscopy. ${ }^{[5]}$ Clinical scores by slit-lamp biomicroscopy range from + I to +4 according to the SUN classification system; ${ }^{[6]}$ however, this is a subjective method and is highly dependent on the experience of the physician. ${ }^{[7]} \mathrm{A}$ better method may be laser flare photometry, an automated technique that quantifies the particulate matter and humoral water in the anterior chamber. ${ }^{[8]}$ Laser flare photometry, in particular, allows the detection of subclinical alterations in the blood-ocular barrier and identifies subtle pathological changes that slitlamp biomicroscopy cannot detect. ${ }^{[9]}$

Cite this article as: Onur İU, Zırtıloğlu S, Sonbahar O, Çavuşoğlu E, Yiğit U. Blood-aqueous barrier deterioration following retained metallic corneal foreign body: A laser flare photometric study. Ulus Travma Acil Cerrahi Derg 2020;26:568-573.

Address for correspondence: Sibel Zırtıloğlu, M.D.

Sağlık Bilimleri Üniversitesi, İstanbul Bakırköy Dr. Sadi Konuk Eğitim ve Araştırma Hastanesi, Göz Kliniği, İstanbul, Turkey

Tel: +90 212 - 4147171 E-mail: sibelI077@hotmail.com

Ulus Travma Acil Cerrahi Derg 2020;26(4):568-573 DOI: 10.14744/tjtes.2019.88560 Submitted: 08.05.2019 Accepted: 15.12.2019 Online: I5.06.2020

Copyright 2020 Turkish Association of Trauma and Emergency Surgery 
A correlation between clinical scoring according to SUN classification system and quantitative readings by flare photometry for uveitic eyes has previously been documented. For example, Konstantopoulou et al. ${ }^{[9]}$ evaluated eyes with uveitis by having experienced physicians independently grade eyes according to the SUN classification, while at the same time obtaining flare values with a flare meter to compare flare based scoring. Flare photometry studies have also been used for specific ophthalmologic disorders, including glaucoma and uveitis, as well as in postoperative and posttraumatic cases. ${ }^{[10]}$ However, to our knowledge, no studies have yet evaluated the flare changes in eyes due to non-penetrating trauma with retained corneal FBs, although these injuries would be expected to generate subclinical and subtle changes in the flare detectable by flare meters.

The present study aims to evaluate flare following the breakdown of the $B A B$ induced by non-penetrating ocular injury with retained metallic corneal $\mathrm{FBs}$, focusing on patient age, lesion size, the distance of the FB from the limbus, and FB penetration depth.

\section{MATERIALS AND METHODS}

Flare values are known to increase with age. ${ }^{\left[{ }^{[I]}\right.}$ Therefore, our inclusion criteria limited the patient ages to between 20 and 40 years. Our evaluation included 54 injured eyes of 54 consecutive patients who were referred to our tertiary eye clinic for retained corneal FB removal during September 2017; the healthy fellow-eyes were evaluated as the control group. This study was approved by the institutional review board of the hospital in accordance with the tenets of the Declaration of Helsinki (2017/I I7). Informed consent was obtained from all individual participants in the study. This study was designed as a prospective, cross-sectional, observational study to compare the flare measurements of the affected versus the healthy fellow eyes.

At presentation, the patients were examined for best-corrected visual acuity according to the standard decimal chart. Anterior and posterior segment examinations were performed, including measurement of intraocular pressure (IOP). Demographic data were collected, including patient age, occupation, and the number of previous referrals of the affected eye for FB removal. All measurements were conducted after pupil dilatation ( $1 \%$ tropicamide). The healthy control felloweyes were also evaluated clinically and by laser flare photometry. Other collected data included the referral time from the injury, the size of the corneal FB and its distance to the limbus, as well as the penetration site into the cornea (epithelium, superficial stroma, or deep stroma) as recorded by biomicroscopy examination.

The retained corneal FBs and rust were removed using a 25-gauge needle under local anesthesia provided by topical proparacaine hydrochloride (Alcaine $0.5 \%$, Alcon Laboratories
Inc., Fort Worth, TX) until no residual rust staining was evident. The size of the corneal epithelial defect was measured in millimeters after the removal of the corneal FB. Topical antibiotic treatment (Ofloxacin four times a day and Tobramycin ointment two times a day) was prescribed after the FB removal.

Seven measurements were recorded with the laser flare photometer (LFM, Kowa FM-700, Kowa Company Ltd., Tokyo, Japan) under a background scatter of $<10 \%$ immediately after removal of the corneal FB. The lowest and highest readings were discarded, and the mean of the five remaining values was recorded according to the manufacturer's guidelines. Measurements were deleted if they were selected by the machine's error level setting as outliers. All patients were treated and assessed by the same examiner (O.S.). Measurements were performed in a darkened room.

Exclusion criteria included any conditions that could affect the measurements of the KOWA FM-700 laser flare photometer, such as corneal scarring, residual rust rings, or incomplete foreign body removal at enrollment; a narrow anterior chamber; extensive posterior synechiae; mature cataract, hyphema, history of uveitis, vitreous hemorrhage, ocular surgery within the past three months, use of anti-glaucoma drugs, or non-inflammatory posterior segment disorders (i.e., diabetic retinopathy, retinal vein occlusion, retinitis pigmentosa, or choroidal melanoma). ${ }^{[8,12,13]}$ No patients had infectious keratitis at the time of corneal FB removal.

\section{Statistical Analysis}

All data were analyzed using IBM SPSS Statistics for Windows Version 21.0 (IBM Corp., Armonk, NY, US). Data were described as means and standard deviations (Mean $\pm \mathrm{SD}$ ) and percentages. The distribution of the data was evaluated using the Kolmogorov-Smirnov test. The Mann-Whitney $U$ and Kruskal-Wallis tests were used to analyze quantitative independent data. The Wilcoxon test was used to analyze the dependent quantitative data, and Spearman correlation analysis was used for correlation analysis. The effect level was assessed by univariate and multivariate logistic regression analysis. P-values less than 0.05 were considered statistically significant.

\section{RESULTS}

All 54 patients were male, and their mean age was $32.9 \pm 9.5$ years. The patient age and anterior chamber flare values showed no significant correlation $(p=0.450)$. The occupations of the patients were metal grinding (30.2\%), construction (22.6\%), and electrical installation (1 I.3\%). No statistically significant difference was noted for flare measurements among the patients in their distinct occupational groups. All injuries resulted from high-velocity metallic FB spinning off from cutting and chopping machines the patients had been using. The mean flare value was significantly higher for the eyes 


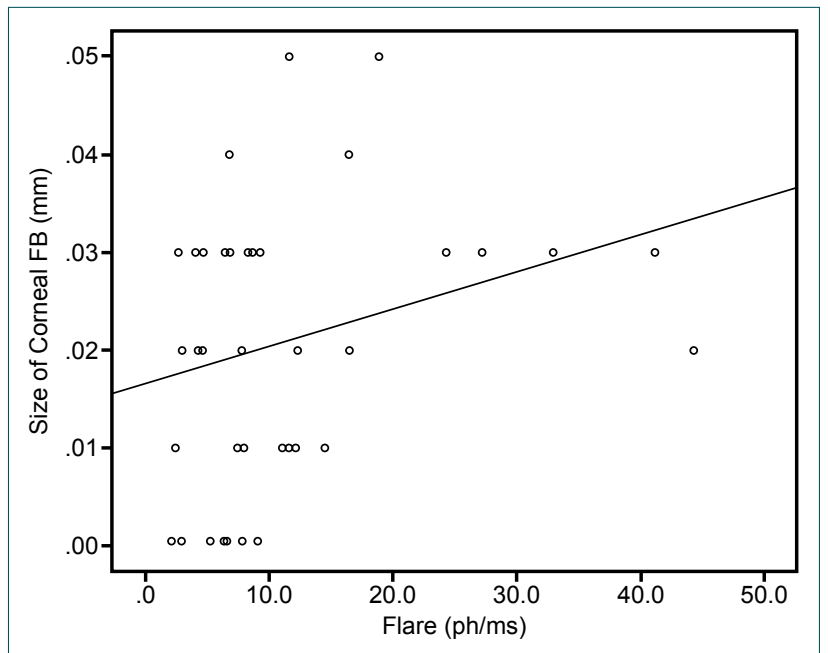

Figure 1. Size of corneal foreign body and flare.

with corneal FB than for the fellow control eyes ( $11.35 \pm 14.17$ vs. $6.30 \pm 3.81 ; p=0.014)$.

The mean diameter of the largest corneal FBs was $0.27 \pm 0.21$ $(0.05-5.00) \mathrm{mm}$. A significant moderate correlation $(r=0.320$, $p=0.02 \mathrm{I}$ ) was detected between the flare value and the size of the corneal FB (Fig. I). Flare values according to the history of previous corneal FB removals are shown in Table I. A statistically significant difference was noted between the mean flare values of the eyes with no previous removal, one previous removal, and multiple previous removals of corneal

Table I. Flare values in relation to the number of previous foreign body removals

\begin{tabular}{lcccc}
\hline $\begin{array}{l}\text { Number of previous } \\
\text { corneal FB removals }\end{array}$ & $\mathbf{n}$ & $\%$ & $\begin{array}{c}\text { ph/ms } \\
\text { (Mean } \pm \text { SD) }\end{array}$ & $\mathbf{p}$ \\
\hline None & 21 & 52 & $13.4 \pm 17.2$ & 0.024 \\
\hline & 9 & 23 & $14.6 \pm 14.6$ & \\
$>1$ & 10 & 25 & $5.5 \pm 2.2$ & \\
\hline
\end{tabular}

FB: Foreign body; SD: Standard deviation.

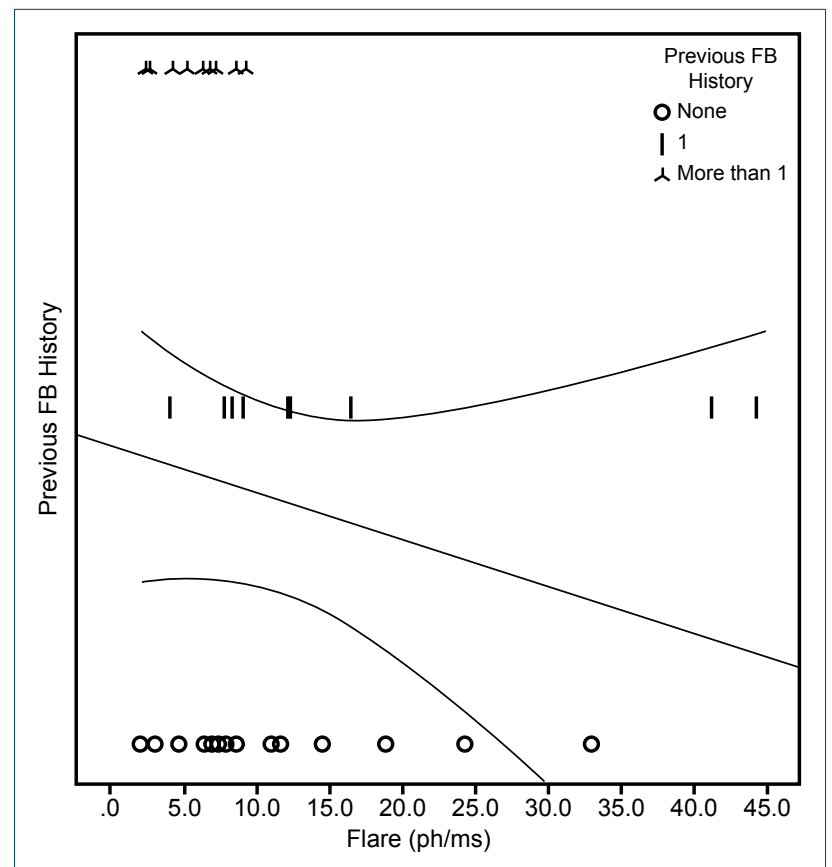

Figure 2. Flare and number of previous removals.

$F B s(p=0.024)$. No significant difference was observed between the mean values of flare in the eyes with one previous removal and no previous removal of corneal $F B s(p=0.375)$, whereas the value of the flare was significantly lower in eyes with multiple previous removals than in the other eyes $(p=0.029)$ (Fig. 2). Notably, the age of the patients did not show any significant correlation with the number of prior corneal FB removals $(p=0.330)$.

The mean distance between the corneal FB and limbus was $2.97 \pm 1.55(0.01-5.00) \mathrm{mm}$. No significant correlation was detected between the flare value and the limbal distance $(p=0.793)$. Corneal FBs were located in the epithelium in $24.5 \%$ of the patients, in the superficial stroma in $60.4 \%$, and in the deep stroma in $15.1 \%$, respectively. No significant differences were found for the flare values among the eyes with deep stromal, superficial stromal, and epithelial corneal FB locations $(p=0.089)$.

Table 2. Logistic regression analysis of parameters in differentiating between low and high flare values

\begin{tabular}{|c|c|c|c|c|c|c|}
\hline \multirow[t]{2}{*}{ Flare (Low $[<8 \mathrm{ph} / \mathrm{ms}]$ vs High $[\geq 8 \mathrm{ph} / \mathrm{ms}])$} & \multicolumn{3}{|c|}{ Univariate model } & \multicolumn{3}{|c|}{ Multivariate model } \\
\hline & OR & (Cl 95\%) & $\mathbf{p}$ & $\mathbf{O R}$ & (Cl 95\%) & $\mathbf{p}$ \\
\hline Age & 1.01 & $0.95-1.07$ & 0.764 & & & \\
\hline Number of FB removals ( $\leq I$ vs $>I$ ) & 0.37 & $0.17-0.84$ & 0.017 & 0.39 & $0.17-0.87$ & 0.022 \\
\hline Depth of corneal penetration & 0.87 & $0.42-1.82$ & 0.718 & & & \\
\hline Referral time & 1.00 & $0.57-1.76$ & 0.991 & & & \\
\hline Distance of FB to limbus (mm) & 0.73 & $0.47-1.14$ & 0.166 & & & \\
\hline Size of FB (mm) & 36.7 & $1.4-960$ & 0.031 & 58.4 & $1.5-2199$ & 0.028 \\
\hline
\end{tabular}


The corneal FB was removed within 12 hours in $15.1 \%$ of the patients, between 12 and 24 hours in $34 \%$, between 24 and 48 hours in $32.1 \%$, and after 48 hours in $18.9 \%$. The differences in flare values according to the referral time were not statistically significant $(p=0.705)$.

Table 2 shows the logistic regression analysis. The high vs. low values for flare showed significant effects in both the univariate and multivariate models for the number of previous FB removals and the size of the FB $(p<0.05)$.

\section{DISCUSSION}

Non-penetrating ocular injury from a retained corneal FB is among the most common reasons for referrals to the emergency ophthalmology clinics in our country. ${ }^{[1]}$ The male predominance in the patient demographics is related to the high proportion of injuries occurring in industrial work environments, as shown in this study. A retained metallic corneal FB is a common presentation at the ophthalmology emergency service and has the potential to cause ocular morbidity. ${ }^{[14,15]}$ In the present study, we searched for the subtle inflammatory response evoked by the corneal FB and possible influencing factors. We found a significantly higher mean flare value in the eyes with the retained corneal FBs than in the healthy fellow eyes, and the flare level showed a moderate correlation with the size of the corneal FB. A statistically significant difference also existed between groups according to the previous history of corneal FB removal.

The objectivity and reproducibility of laser flare photometry have been documented repeatedly, ${ }^{[16]}$ as the relationship between the SUN classification system and laser flare photometry readings have been studied in numerous reports. ${ }^{[9,17]}$ The clinical grading system for flare measurement was confirmed as quite subjective, whereas laser flare photometry allowed quantitative measurements and could discern even minute changes. Laser flare photometry values correlate well with the clinical flare grades based on slit-lamp examination; however, a wide range of laser flare photometry measurement values corresponding to specific clinical grades, with a notable overlap between grades. ${ }^{[18,19]}$ In our study, the mean flare values induced by corneal FBs predominantly fell into the faint or moderate stages of flare, according to the SUN system.

Changes in flare may actually indicate a significant alteration in disease activity or recovery of the blood-aqueous barrier. Laser flare photometric studies involve a broad range of clinical entities, from uveitis of all types to cataract surgery, corneal and refractive surgery, glaucoma, and retinal vascular disorders. ${ }^{[20]}$ Lages et al. ${ }^{[2]]}$ reported 664 and $742 \mathrm{ph} / \mathrm{ms}$ values in two cases with endophthalmitis following intravitreal injection of anti-VEGF and proposed a cut of the level of $>50$ $\mathrm{ph} / \mathrm{ms}$ on day 3 to promote evaluation for endophthalmitis. Mean flare values were reported in the $300-500 \mathrm{ph} / \mathrm{ms}$ range in several other uveitis studies, while $10-40 \mathrm{ph} / \mathrm{ms}$ peak values were shown immediately after penetrating keratoplasty and corneal refractive procedures or in the acute phase of corneal graft rejection. ${ }^{[20,22]}$ The flare values in our study appear particularly comparable to values reported in the keratoplasty and refractive studies mentioned above, which suggests that similar pathophysiological responses may be of concern.

Damage to the epithelial integrity causes the release of some chemoattractants that attract polymorphonuclear leukocytes (PMNs) from the limbal vessels and tear film. PMNs then invade the stroma to engulf and eliminate debris. ${ }^{[23]}$ Because the corneal FBs were mostly removed within 48 hours, as shown in our study, we considered that the flare in this scenario was likely to be relevant to the early phase of inflammation. However, Rosenbaum et al. ${ }^{[24]}$ evaluated the correlation of ocular deformation with BAB breakdown and showed that inflammation flared up as the deformation intensified. Therefore, the moderate correlation between flare and the size of corneal FB determined in the present study might indeed be attributable to the impact force leading to ocular deformation, which was indirectly related to the size of the corneal FBs.

In this study, eyes with a history of multiple previous corneal FB removals also had a significantly lower mean flare level than the other eyes, which requires an explanation. We cautiously attribute this finding to anterior chamber associated immune deviation (ACAID), which is a form of immune tolerance to alloantigens placed in the anterior chamber of the eye. ACAID downregulates the antigen-specific delayed-type hypersensitivity (DTH) response while promoting the production of non-complement fixing antibodies and humoral immunity. ${ }^{[25]}$ This process is related to F4/80+antigen presenting cells (APC), which capture intraocular antigens, enter the bloodstream, and migrate to the marginal zone of the spleen, where their interactions with CD4+ T cells, $\gamma \delta T$ cells, $B$ cells, and natural killer (NK) T cells result in the generation of two groups of antigen- specific regulatory $T$ cells (Tregs): CD4+ CD25+ Tregs and CD8+ Tregs. ${ }^{[26]}$ However, we can only speculate about the possibility of ACAID triggered by multiple exposures to metallic corneal FBs, given the scope of our study. To the best of our knowledge, no ophthalmic papers have mentioned this concept. In fact, following recurrent graft rejections characterized by DTH to donor alloantigens and leukocytic cellular infiltration of the graft site, the host becomes more sensitized, and the time to rejection decreases. ${ }^{[27,28]}$

This study has some important limitations that should be recognized. One is that the evaluation of ocular inflammation was cross-sectional, for practical reasons. A longitudinal follow-up may display the course of inflammation in detail and may indicate the timing of the peak response or accelerated phase. A second limitation is that "metallic" is a general definition, and the variability in the exact chemical composition of the FB is highly likely to stimulate a variable inflammatory response. 
In conclusion, this preliminary descriptive flare photometry study revealed that subtle intraocular inflammation might be evoked by metallic corneal FB exposure and might show some degree of variability. Further studies with metallic or non-metallic FB exposures are required to confirm or disprove our findings and to verify the potential relevance to the clinical setting.

Ethics Committee Approval: Approved by the local ethics committee.

Peer-review: Internally peer-reviewed.

Authorship Contributions: Concept: I.U.O.; Design: E.Ç.; Supervision: I.U.O.; Fundings: O.S.; Materials: U.Y.; Data: O.S.; Analysis: I.U.O., S.Z.; Literature search: I.U.O., S.Z.; Writing: I.U.O., S.Z.; Critical revision: İ.U.O.

Conflict of Interest: None declared.

Financial Disclosure: The authors declared that this study has received no financial support.

\section{REFERENCES}

1. Ozkurt ZG, Yuksel H, Saka G, Guclu H, Evsen S, Balsak S. Metallic corneal foreign bodies: an occupational health hazard. Arq Bras Oftalmol 2014;77:81-3. [CrossRef]

2. Welch LS, Hunting KL, Mawudeku A. Injury surveillance in construction: eye injuries. Appl Occup Environ Hyg 2001;16:755-62. [CrossRef]

3. Tugal-Tutkun I, Herbort CP. Laser flare photometry: a noninvasive, objective, and quantitative method to measure intraocular inflammation. Int Ophthalmol 2010;30:453-64. [CrossRef]

4. Freddo TF. A contemporary concept of the blood-aqueous barrier. Prog Retin Eye Res 2013;32:181-95. [CrossRef]

5. Martin R. Cornea and anterior eye assessment with slit lamp biomicroscopy, specular microscopy, confocal microscopy, and ultrasound biomicroscopy. Indian J Ophthalmol 2018;66:195-201.

6. Trusko B, Thorne J, Jabs D, Belfort R, Dick A, Gangaputra S, et al; Standardization of Uveitis Nomenclature (SUN) Project. The Standardization of Uveitis Nomenclature (SUN) Project. Development of a clinical evidence base utilizing informatics tools and techniques. Methods Inf Med 2013;52:259-65,S1-6. [CrossRef]

7. Li Y, Lowder C, Zhang X, Huang D. Anterior chamber cell grading by optical coherence tomography. Invest Ophthalmol Vis Sci 2013;54:25865. [CrossRef]

8. Ladas JG, Wheeler NC, Morhun PJ, Rimmer SO, Holland GN. Laser flare-cell photometry: methodology and clinical applications. Surv Ophthalmol 2005;50:27-47. [CrossRef]

9. Konstantopoulou K, Del'Omo R, Morley AM, Karagiannis D, Bunce C, Pavesio C. A comparative study between clinical grading of anterior chamber flare and flare reading using the Kowa laser flare meter. Int Ophthalmol 2015;35:629-33. [CrossRef]

10. Sahu S, Ram J, Bansal R, Pandav SS, Gupta A. Effect of topical ketorolac $0.4 \%$, nepafenac $0.1 \%$, and bromfenac $0.09 \%$ on postoperative inflammation using laser flare photometry in patients having phacoemulsification.
J Cataract Refract Surg 2015;41:2043-8. [CrossRef]

11. El-Harazi SM, Ruiz RS, Feldman RM, Chuang AZ, Villanueva G. Quantitative assessment of aqueous flare: the effect of age and pupillary dilation. Ophthalmic Surg Lasers 2002;33:379-82.

12. Yu SY, Nam DH, Lee DY. Changes in aqueous concentrations of various cytokines after intravitreal bevacizumab and subtenon triamcinolone injection for diabetic macular edema. Graefes Arch Clin Exp Ophthalmol 2018;256:39-47. [CrossRef]

13. Nagasaka $Y$, Ito $Y$, Ueno $S$, Terasaki H. Increased aqueous flare is associated with thickening of inner retinal layers in eyes with retinitis pigmentosa. Sci Rep 2016;6:33921. [CrossRef]

14. Luo $Z$, Gardiner M. The incidence of intraocular foreign bodies and other intraocular findings in patients with corneal metal foreign bodies. Ophthalmology 2010;117:2218-21. [CrossRef]

15. Gonul S, Bozkurt B, Okudan S. Metallic corneal foreign bodies: an occupational health hazard. Arq Bras Oftalmol 2014;77:411. [CrossRef]

16. Heinz C, Zurek-Imhoff B, Koch J, Rösel M, Heiligenhaus A. Long-term reduction of laser flare values after trabeculectomy but not after cyclodestructive procedures in uveitis patients. Int Ophthalmol 2011;31:20510. [CrossRef]

17. Agrawal R, Keane PA, Singh J, Saihan Z, Kontos A, Pavesio CE. Classification of semi-automated flare readings using the Kowa FM 700 laser cell flare meter in patients with uveitis. Acta Ophthalmol 2016;94:e135-41.

18. Conart JB, Kurun S, Ameloot F, Tréchot F, Leroy B, Berrod JP. Validity of aqueous flare measurement in predicting proliferative vitreoretinopathy in patients with rhegmatogenous retinal detachment. Acta Ophthalmol 2017;95:e278-83. [CrossRef]

19. Ohara K, Okubo A, Miyazawa A, Miyamoto T, Sasaki H, Oshima F. Aqueous flare and cell measurement using laser in endogenous uveitis patients. Jpn J Ophthalmol 1989;33:265-70.

20. Sawa M. Laser flare-cell photometer: principle and significance in clinical and basic ophthalmology.Jpn J Ophthalmol 2017;61:21-42. [CrossRef]

21. Lages V, Gehrig B, Herbort CP Jr. Laser flare photometry: a cost-effective method for early detection of endophthalmitis after intravitreal injection of anti-VEGF agents. J Ophthalmic Inflamm Infect 2018;8:23. [CrossRef]

22. Küchle M, Nguyen NX, Naumann GO. Aqueous flare following penetrating keratoplasty and in corneal graft rejection. Arch Ophthalmol 1994;112:354-8. [CrossRef]

23. Eiferman RA, Schulz GS, Nordquist RE, Waring GO. Corneal wound healing and its pharmacologic modification after refractive keratotomy. In: Waring GO, editor. Refractive Keratotomy for myopia and astigmatism. 3th ed. St Louis: Mosby; 1992. p. 749-77.

24. Rosenbaum JT, Tammaro J, Robertson JE Jr. Uveitis precipitated by nonpenetrating ocular trauma. Am J Ophthalmol 1991;112:392-5. [CrossRef]

25. Streilein JW. Ocular immune privilege: therapeutic opportunities from an experiment of nature. Nat Rev Immunol 2003;3:879-89. [CrossRef]

26. Taylor AW. Ocular immune privilege. Eye (Lond) 2009;23:1885-9.

27. Abudou M, Wu T, Evans JR, Chen X. Immunosuppressants for the prophylaxis of corneal graft rejection after penetrating keratoplasty. Cochrane Database Syst Rev 2015;(8):CD007603. [CrossRef]

28. Zhang T, Li Z, Liu T, Li S, Gao H, Wei C, et al. Cyclosporine a drugdelivery system for high-risk penetrating keratoplasty: Stabilizing the intraocular immune microenvironment. PLoS One 2018;13:e0196571. 
ORİIINAL ÇALIŞMA - ÖZET

\section{Lazer flare fotometri ile korneal yabancı cisim sonrası kan-aköz bariyerinde bozulmanın gösterilmesi}

\section{Dr. İsmail Umut Onur, Dr. Sibel Zırtıloğlu, Dr. Ozan Sonbahar, Dr. Ercan Çavuşoğlu, Dr. Ulviye Yiğit}

Sağlık Bilimleri Üniversitesi, İstanbul Bakırköy Dr. Sadi Konuk Eğitim ve Araştırma Hastanesi, Göz Hastalıkları Kliniği, İstanbul

AMAÇ: Metalik yabancı cisim maruziyeti sonrası oluşan korneal yaralanmalarda lazer fotometri kullanarak ön kamara flare değişikliklerini değerlendirmek.

GEREÇ VE YÖNTEM: Bir gözünde yabancı cisim yaralanması olan 54 hastanın sağlıklı gözü karşılaştırmalı, gözlemsel ve kesitsel bir çalışmada incelendi. Flaredeki değişkenlik demografik özellikler, önceki maruziyetlerin öyküsü, korneal yabancı cismin yaralı korneadaki yeri ve penetrasyonuna göre analiz edildi.

BULGULAR: Korneal yabancı cisim gelen gözlerde ortalama flaremetre değeri diğer kontrollere göre anlamlı derecede yüksekti (sırasıyla,

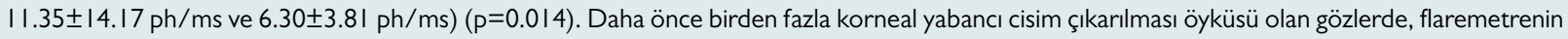
ortalama değeri diğerlerinden anlamlı derecede düşüktü $(p=0.029)$.

TARTIŞMA: Korneanın yabancı cisme maruz kalmasıyla flare değeri artar. Bununla birlikte, daha önce birçok korneal yabancı cisme maruz kalma durumunda, flare değeri muhtemelen korneanın duyarsızlaştırılmasından dolayı nispeten düşük olabilir.

Anahtar sözcükler: Korneal yabancı cisim; lazer flare fotometri; ön kamara reaksiyonu.

Ulus Travma Acil Cerrahi Derg 2020;26(4):568-573 doi: 10.14744/tjtes.2019.88560 